\title{
Digital feminist activism: Analyzing Jakarta Feminist as a collective identity, resources, network, information dissemination, and mobilization
}

\section{Aktivisme feminis digital: Menganalisis Jakarta Feminist sebagai identitas kolektif, sumber daya, jaringan, diseminasi informasi, dan mobilisasi}

\author{
Rifka Annisa ${ }^{\circledR}$ \\ Department of Sociology, Faculty of Social and Political Sciences, University of Indonesia \\ Depok, 16424, West Java Province, Indonesia \\ E-mail of corresponding author: rifkaannisahermanto@gmail.com
}

\begin{abstract}
The use of social media for feminist activism in Indonesia has increased in decades. Some studies have mentioned digital feminist activism as the three intersectional relations of collective agenda, civic network, and digital infrastructure. To deepen, this study aims to analyze digital feminist activism works to organize collective identities, develop resources, coordinate networks, disseminate information, and mobilize social actors, in the case of Jakarta Feminist through a qualitative approach combined with social and textual network analysis. As a result, the Jakarta Feminist collective's identity formed based on their identities, concerns, and defaces to the right of all Indonesian women, and other minorities group succeeded in developing resources in the form of moral, cultural, material, human, and network. Jakarta Feminist disseminated activism information by using social media features, and their members' ties. Mobilized actors by conducting internal group planning, themes, and hashtags, boosted by social media personalities digital campaigns, individual and cross-organization. This study concluded that feminist digital activism running by the combination of their work in online and offline spheres. The crosssectional interrelated of feminist activism to other issues, movements, and entities are interesting topics for future research.
\end{abstract}

Keywords: digital feminist activism; Jakarta Feminist; social network analysis; textual network analysis

\begin{abstract}
Abstrak
Penggunaan media sosial untuk aktivisme feminis di Indonesia telah meningkat dalam beberapa dekade. Beberapa penelitian menyebutkan aktivisme feminis digital sebagai tiga hubungan interseksional dari agenda kolektif, jaringan sipil, dan infrastruktur digital. Untuk lebih mendalam, studi ini bertujuan untuk menganalisis karya aktivisme feminis digital untuk mengorganisir identitas kolektif, mengembangkan sumber daya, mengoordinasikan jaringan, menyebarkan informasi, dan memobilisasi aktor sosial, dalam kasus Jakarta Feminist melalui pendekatan kualitatifyang dipadukan dengan analisis jaringan sosial dan tekstual. Alhasil, identitas kolektif Jakarta Feminist yang terbentuk berdasarkan identitas, kepedulian, dan penghinaan terhadap hak seluruh perempuan Indonesia, dan kelompok minoritas lainnya berhasil mengembangkan sumber daya berupa moral, budaya, material, manusia, dan jaringan. Jakarta Feminist menyebarkan informasi aktivisme dengan menggunakan fitur media sosial, dan ikatan anggotanya. Memobilisasi aktor dengan melakukan perencanaan kelompok internal, tema, dan tagar, didorong oleh kampanye digital kepribadian media sosial, individu dan lintas organisasi. Studi ini menyimpulkan bahwa aktivisme digital feminis berjalan dengan kombinasi karya mereka di ranah online dan offline. Keterkaitan lintas-bagian aktivisme feminis dengan isu, gerakan, dan entitas lain merupakan topik yang menarik untuk penelitian di masa depan.
\end{abstract}

Kata Kunci: aktivisme feminis digital; Jakarta Feminist; analisis jaringan sosial; analisis jaringan tekstual

\section{Introduction}

Historically, the use of the internet and new media in Indonesia for the benefit of democratic practices has occurred since the Reformation period in 1998 (Suwana 2020). Social media is used as a tool to organize support for social and political change by a group or individual to achieve a particular agenda, it can be said as digital activism and empirically founds oriented towards promoting economic, social, political change, and organizing public campaigns (Gerbaudo \& Treré 2015, Suwana 2020, Wijayanti \& Rosalinda 2020). 
However, in the discussion of the existence of feminists on the internet mentioned by Vogt \& Chen (2001) that the internet has become "a central tool" for feminists to develop resources, organize collective identities, coordinate networks, produce knowledge, disseminate information, and mobilize actors. Then, Parahita (2019) study explained digital feminist activism as the three intersectional relations of collective agenda, civic network, and digital infrastructure. The collective agendas are not always resultoriented, but even as identification of individuals or groups with certain identities is the first step in introducing self-existence as part of their citizenship or as simple as share feminist knowledge (Jackson 2018). Slightly to the emergence of 20th century new social structures caused by the feminist movement (Castell 2000), it long ago arises because there are political opportunities for women to organize, form collective identities, resources availability, and some basic structural contexts which able to mobilize women collectively and interprets their interactionally, structurally, and culturally losses and demands (Pelak et al. 2006). While at that time the feminist movement was known to be driven by women who shared experiences, resistances, and created collective identity, as well as resource availability, political opportunities, and organizations (Buechler 1990). The most popular perspective such as collective behavior, resource mobilization, and new social movements (McAdam 1992, McCarthy \& Zald 1977, Morris 1984, Turner \& Killian 1987, Melucci 1998, Tarrow, 2011) could be used to explain the feminist movement resistance, ideology, and collective identity and ensure the intersection of organizational settings, resources, and political contexts of the emergence, nature, and direction of its movements (Pelak et al. 2006).

Recently, feminism in the internet discourse has been interesting to explore. In Indonesia, feminists are openly identify themselves on social media namely: @jakartafeminist, @indonesiafeminis, @ muslimahfeminis,@perempuanfeminis, and@womensmarchjkt (Parahita, 2019), as before it found oriented to the issue of women, girls, and women labors mentioned as \#NyalaUntukYY, the case of Baiq Nuril \#saveibunuril, \#KitaAgni, the case of mass miscarriage of female workers in the Aice factory, and \#womensmarchjakarta (KPI 2016, Parahita 2019, Wismabrata 2020). Globally, some popular examples are \#MeToo, \#SayHerName, and \#Womensmarch (Crenshaw et al. 2017, Jamierson 2016, Zeng 2020). Meanwhile, the discourse on the Indonesian women's movement from existing studies is still dominated by the discussions about the influence of Islamic organizations and others that place the feminist movement in the pre-colonial context of the twentieth century and the New Order era, as well as issues of nation-state formation, ideology, and state intervention in gender relations (Parahita 2019).

Several scholars have discussed digital activism and found the role of youth agencies as actors behind the phenomenon of digital activism in Indonesia (Parahita 2019, Suwana 2021, Saud \& Margono 2021), and it empirically find that Jakarta Feminist has been run digital activism by the youth agency (Parahita 2019). To continue, complement, deepen, and add new perspectives to this topic, this research is about analyzing the question of how digital feminist activism works to organize collective identities, develop resources, coordinate networks, disseminate information, and mobilize social actors. Arguing of feminist digital activism has used social media for forming their collective identity, developing resources (in several types such as moral, cultural, socio-organizational, human, material, and network resource), coordinating social network, disseminating information, and mobilizing the social actors through the screen to street. This study presents a case study of a feminist organization named Jakarta Feminist as one of the first Indonesian rising feminist digital activist groups and the initiator of Women's March Jakarta (WMJ) and analyzes their Twitter social and textual networks with the @jakartafeminist account and hashtag \#PuandanKawanMelawan to record their networks and discourse empirically in the digital setting.

\section{Research Methods}

This study takes a qualitative research approach that combines in-depth interviews and a digital-based study. Emphasized based on the empirical experience of many researchers who consider the enormous opportunities available in the phenomenon of the development and spread of the Internet (Palys \& 
Atchison 2012). Thus, these many opportunities are interesting, especially of the internet dominance and its implications for sampling and data collection of social networking sites as Twitter for studies on digital feminist activism (Palys \& Atachison 2012, Parahita 2019), and discussing Jakarta feminists as case study to get the results of an in-depth analysis related to an information-based research orientation. Primary and secondary data are used here when in-depth interview data is collected online, and the informants are KAT as Communication Manager and NOV as Program Manager of Jakarta Feminist. Secondary data are @jakartafeminist and \#PuandanKawan Twitter data, collected with data scraping techniques using Netlytic a text analysis site and community-based social network for social media researchers and educators in studying public discourse on social media (Gruzd \& Mai 2020).

The in-depth interview data was analyzed with data reduction and display (Miles \& Huberman 1992). The Twitter data are analyzed in two ways with social network analysis (SNA) and textual network analysis (TNA) using Gephi Software. The SNA includes three aspects such as modularity to identify groups in the network, degree centrality to identify the number of connections an actor has, and eigenvector centrality to indicate an influential actor on the network (Blondel et al. 2008). The TNA is an intersection analysis method between SNA and Content analysis, by looking at the quality and structure of the relationship between words to identify the central words in the body of the text and groups of words. Words are actors/nodes and ties/networks (links/edges) judging from how often they appear together (co-occurrence/co-appearance) with other words (Segev 2020). In total, 270 tweets were collected in the @jakartafeminist's Twitter network. In the WMJ 2021 with \#PuandanKawanMelawan's Twitter network, a total of 448 tweets were collected. The data was validated in two ways, primary data using triangulation and secondary data using accountability data (Denzin 1978, Arnaboldi et al. 2017). The research ethics related to the use of Twitter data based on the British Sociological Association such as: comply with Twitter's Developer Agreement policies, only use it for academic research purposes, store all information of every Twitter user confidentially on a secure server with password protection, maintain user anonymity in research, only present aggregated research information based on data obtained legally and ethically from Twitter APIs (William \& Burnap 2016).

\section{Results and Discussion}

\section{The Jakarta Feminist, who is "them"? Collective identity and resources explanations}

Jakarta Feminist is a feminist digital activist group and originally formed through Facebook named the Jakarta Feminist Discussion Group (JFDG) in 2014, also the initiator of WMJ which has been running since 2017 (Parahita 2019). Analyzing their collective identity, a shortened concept from Melucci (1998) defined as a definition of a collective sense of "them" of certain social movements. Whereas in the activism on social media context, Gerbaudo \& Treré (2012) mentioned the collective identity can be identified using iconography or lexicon such as hashtags or slogans, icons, and names on the accounts of groups or individuals in certain activism. Straightforward to feminism is a collective identity that comes from a group that has common interests, experiences, beliefs, and solidarity among its members (Pelak et al. 2006). The data findings show that Jakarta Feminist stands for the right of women and minority groups in Indonesia. At first, the purpose of founded JFDG was to create a digital safe space for women, and sexual minorities who live in Jakarta and other surrounding cities as a place for discussions, share personal experiences, and advocation for victims of sexual harassment and violence (Parahita 2019). Although with the ease of participation in social media, it has immediately expanded the regional dimension to national, so that their scope of attention is no longer limited to the initial domicile. On Twitter they account named @jakartafeminist and @womensmarchjkt, then for WMJ 2021 specifically used \#PuandanKawanMelawan as the hashtag of 2021, emphasized in these following statements:

"Jakarta Feminist fight for the rights of women and minority groups in Indonesia. Our members have a variety of professions that also have networks with other groups, such as various trade unions. Based on it, we accommodate many issues that come from each interest and problem faced by our group members, more specifically such as gender-based violence, discrimination against sexual minorities such as LGBT." (The informant NOV) 
"Initially, the members were domiciled in JABODETABEK (Jakarta, Bogor, Depok, Tangerang, and Bekasi) but gradually because there were not many groups in other regions that clearly identified themselves as feminist associations, more members from other regions joined the Jakarta Feminist instead so that it was a national scale." (The informant KAT)

"When we started (Women's March Jakarta 2017), it was purely inspired by what the Women's
March was doing in the US, the Women's March Global started contacting us because we use their
logo, but we still have a bargaining position, such as determining our own logo with the addition of
a picture of a Muslim woman wearing a hijab which is important for us because it represents many
women's identities in Indonesia. From the first, we have always used slogans or hashtags because
it's managed to get attention and move the masses, and we have our own process in determining
what slogans we will use annually." (The informant KAT)

To discuss Jakarta Feminist resources, many scholars provide an outstanding concept such as McCarthy \& Zald (1977), Tarrow (2011), Edwards a\&nd McCarthy (2004), and on the internet base activism by Sokolov et al. (2018). This study tries to combine both types of classification as First, moral resources are legitimacy (obtained in the form of organizational legality validated by the relevant state institution), solidarity (obtained by joining solidarity with local-global feminist movements), and sympathy (obtained by bringing the representative problems of its members into collective problems that become a common problem if associated with shared experiences and mentioned to theirs demand). That comes in the following statements, "in 2019 Jakarta Feminist became a legal association recognized by the Indonesian Ministry of Law and Human Rights. We registered that time as a membership-based association" (The informant KAT).

\begin{abstract}
"We joined SEAFAM (the Southeast Asian Feminist Movement), and we always try to keep in touch with feminist friends from other countries to support and introduce their issues, as well as maintain relationships with many grassroots organizations and networks in Indonesia, such as Gerak Perempuan, and international Solidarity networks especially in Asia. Southeast Asia, such as Malaysia, Myanmar, and the Philippines, because they are still closely related and have problems with similar contexts." (The informant NOV)

"Our group uses an intersectional approach to be able to attract many people to move and join the feminist movement that we create through raising issues that are most experienced by many people, many issues are represented from problems faced by our group members to local political conditions such as the issue of draft laws on the Elimination of Sexual Violence (RUU Penghapusan Kekerasan Seksual)." (The informant KAT)
\end{abstract}

Second, the cultural resource explained here as knowledge and information, as in Parahita (2019), they have the feminist knowledge and capacity to spread it, through other social and public media campaigns such as Feminist Festivals, training, or workshops and discussion. Third, the socio-organizational resource as organization and community, Jakarta Feminist has eight staff in the organizational structure and alliances of various communities and organizations during WMJ. Forth, the material resources are digital technology, financial, and physical. Jakarta Feminist are fully aware that digital technology such as social media has the capacity to promote their activism (Parahita 2019). They have internal funding by the members and commercial public events as financial resources, and physical resources as simply as the attendances of their members. As finds in the following statements, "on social media members help creatively, such as making Instagram filters, organizing Feminist Festivals, training or workshops, and discussions" (The informant KAT).

"So, we now have eight staff, including the Director, Communication Manager, Program Manager, Graphic Designer, Advocacy, Partnership, Administrative, and Finance Staff. In WMJ, since 2017 approximately 30 communities and organizations, and in 2018, 65 organizations are included and the totals always increasing each year." (The informant KAT) 
"At the opening of membership, we usually make a fee (for internal funding) and members get many benefits, such as discounted ticket prices to events we organize such as Feminist Festivals, training or workshops, discussions, creating membership programs." (The informant KAT)

Fifth, the human resources are identified by the number of their members from the JFDG's Facebook group in total 2.388 have joined in 2021, of these members have diverse professions and relationships with many affiliations, including members and affiliations with social media personality actors. Last, network as resources is limited as relationships of Jakarta Feminist with movement organizations and other parties, interactions between actors. Meanwhile, in our observation their network can be described more thoroughly by mentioning the related entities, such as the global and local networks with SEAFAM, Women's March Global, and Gerak Bersama, their network ties are formed together with activism and the network of feminist activists that had existed before. Both mentioned in these following statements: "We count the number of members in the group around 2,000 . We never pursued these actors
(social media personality), but this happened so naturally, because they already have an interest
in feminism, and these figures are very influential on media coverage, the voice on social media.
We really appreciate their support and contribution, but on the other hand, they are part of this
movement or activism itself." (The informant KAT)

"They (social media personality) share our social media content, such as reposts on their accounts, so that it adds a lot of people who are interested in what we do, and afterwards leads to closer relationships such as friendship." (The informant NOV)

\begin{abstract}
"What really makes us sustainable is the network of many affiliates we have. Jakarta feminists have always been seen as an association, but we are a network. We always try to alliance more groups, because we want to be a catalyst for the women's movement in Indonesia. Includes women's organizations and communities which already exist and have worked for a long time for rights and locality issues." (The informant KAT)
\end{abstract}

\title{
Network coordination and Social Network Analysis (SNA)
}

Jakarta Feminist has an intertwined network of their members and affiliations as mentioned above. Meanwhile, a network according to Chafetz (2006) and Swank \& Fahs (2017) is a form of "social senses" as a natural process of the emergence and development of a movement. Wasserman \& Faust (1994) defined social networks as connections between social actors. Networks tied not only because of interactions between social movements and the media, certain authorities, and other movement organizations and other related parties (McCarthy \& Zald 1977, Edwards \& McCarthy 2004) but also network ties can be one of the determinants to the successful mobilization (Muller 1980). In the Twitter network settings, Isa \& Himelboim (2018) mentioned that a network is built by users through interactions such as mentioning or replying to each other. Henceforward, this study tries to analyze the Jakarta Feminists' social network records on Twitter (Figure 1), as the results data identified 269 nodes and 409 links. Analyzed in three aspects, as follows; modularity, degree centrality, and eigenvector centrality (Blondel et al. 2008) to expand the findings of their network ties in the online spaces.

Table 1.

The actor's degree centrality and eigenvector centrality of @jakartafeminist social network

\begin{tabular}{ccccc}
\hline No. & Actor & $\begin{array}{c}\text { Number of } \\
\text { connections/ties }\end{array}$ & \multicolumn{1}{c}{$\begin{array}{c}\text { Actor } \\
\text { Influencel } \\
\text { Eigenvector } \\
\text { Centrality }\end{array}$} \\
\hline 1. & @jakartafeminist & 144 & @jakartafeminist & 1 \\
2. @Nitro_Foxit & 33 & @waltonkate & 0.266667 \\
3. & @waltonkate & 20 & @amnestyindo & 0.213333 \\
4. & @keygen & 16 & @heradiani & 0.186667 \\
5. @amnestyindo & 16 & @InstitutUngu & 0.133333 \\
\hline
\end{tabular}




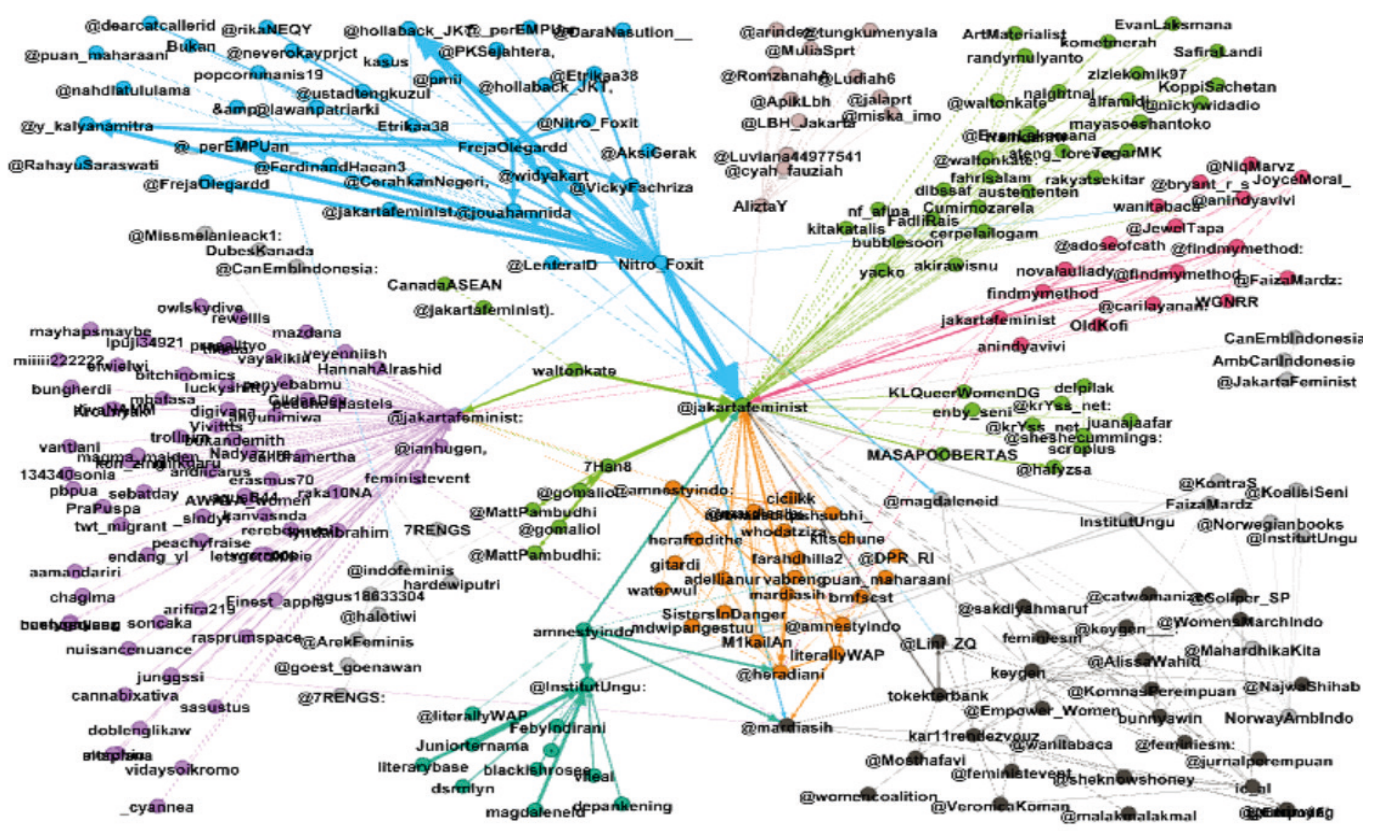

Figure 1.

Social network graph of @jakartafeminist

Source: Personal data

Based on modularity, there are 15 groups of actors in the @jakartafeminist social network (Figure 1). The first group with $26.02 \%$ has 70 social actors. In the group, mention is directed to two social actors, such as social media personality @ianhugen and @jakartafeminist as identified having the most relationships with 144 ties-based degrees centrality and the strongest influence-based eigenvector centrality. Second, a group with $21.93 \%$ has 46 social actors, in-group are known for several social actors such as activist and the director of Jakarta Feminist named @waltonkate as the third-placed in-degree centrality and second eigenvector centrality, organization@CanadaASEAN, and discussion group @KLQueerDG. The third group with 11.9\% has 25 social actors, including @Nitro_foxit as the second-placed in-degree centrality,non-governmental organizations@perEMPUan, politicians@DaraNasution, political parties@PKSejahtera. The fourth group with 10.04\% has 26 social actors, including @keygen as the fourth-placed in-degree centrality, politician@AlissaWahid,Writer@mardiasih, and organizations @ KomnasPerempuan,@womencoalition, and @jurnalperempuan. The fifth group with 8.55\% has 21 social actors, including government agency@DPR_RI, non-governmental organization@amnestyindo, as fifth-placed in-degree centrality and third-placed in eigenvector centrality, and journalist @ heradiani as fourth-placed in eigenvector centrality.

Meanwhile, the sixth and seventh groups with $4.46 \%$ each, have 11 actors. The sixth group recognized the presence of organization@amnestyindo and feminist digital media@magdaleneid. Meanwhile, the seventh group of identified actors tends to focus on advocacy and legal assistance, such as @ $\mathrm{LBH}$ Jakarta, and@ApikLbh. The eighth group with 3.72\% found a total of 9 social actors including @ InstitutUngu as the fifth-placed in eigenvector centrality, @KoalisiSeni,@Kontras,@magdaleneid, @ MahadhiKita,@Wanitabaca. The ninth group with 2.6\% identified as many as 7 social actors including two accounts of feminist organizations@indofeminis, and@lawanpatriarki. The tenth and eleventh groups each with $1.12 \%$ and consists of 3 social actors, including other country government account as AmbCanIndonesie, CanEmbIndonesia. While the eleven groups, Jakarta Feminist member named @waltonkate was identified. In the eleventh group with 1.12\%, one of the 3 social actors, namely, @ KrYss_net is an activism account against child marriage and the other is anonymous accounts. And last three groups, thirteen, fourteen, and fifteen with a percentage and number of actors respectively $0.47 \%$ and 3 actors, including government actors with the account name DebesKanada,@CanEmbIndonesia in the fourteen groups, and @jakartafeminist in the group of fifteen. Meanwhile, Table 1 shows that @ jakartafeminist has a wider social network than other actors. 


\section{Feminism information disseminated to the network discourses}

The process of disseminating ideas or information which is spread based on the understanding and type of movement (feminist movement with feminist ideas) through the interaction of friends, family, and in the context of social media ideas can be spread by the influential accounts (Tarrow 2011, Swank \& Fahs 2017). The spreading of ideas and information runs spontaneously from person to person, place to place and the process occurs and is regulated through social networks among actors (Tarrow 2011). The information disseminated by adjusted to the context of its media. The activists take advantage of features available on social media such as iconography and lexicon or hashtags/slogans, icons, and names to join discourses and networks in activism or digital social movement (Gerbaudo \& Treré 2012). In the context of Jakarta Feminist, empirically to the record @jakartafeminist textual network and discourses, this study conducted a TNA (Figure 2), where was collected 273 corpus (nodes), 743 edges (ties) and grouped to 8 corpus connected in network ties. Each group in the network carries its own discourse theme.

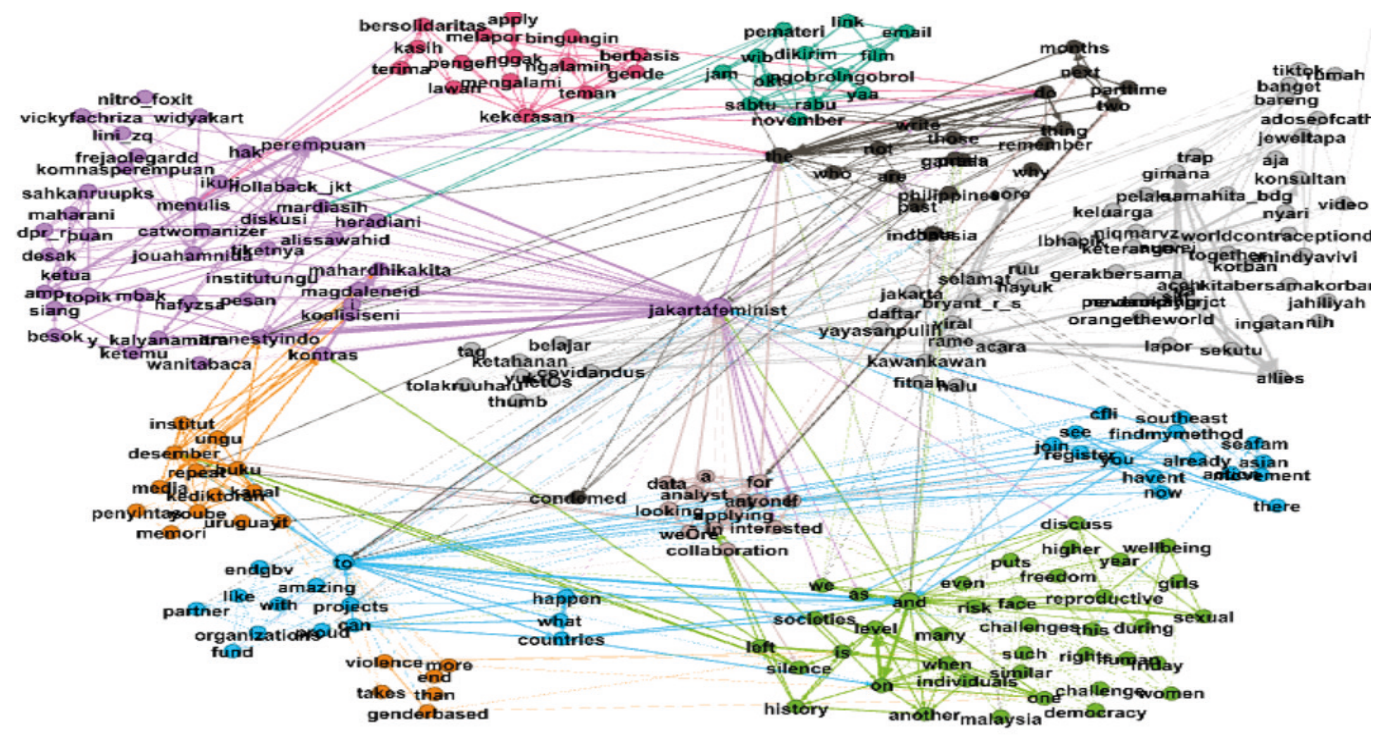

Figure 2.

Textual network graph of @jakartafeminist

Source: Personal data

The first group with $26.1 \%$ bringing the discourse on "Joint the southeast Asian feminist action movement" (SEAFAM), illustrate the network connection to the Southeast Asian-scale movement and stated that Filipino, Indonesian and Malaysian women had the same challenges to democracy, human rights, and freedom in the case of gender-based violence, presence their collective identity which has something in common. The second group with $11.36 \%$ brought discourse related to \#SahkanRUUPKS with an invitation to the "Do The Write Thing" campaign, also linking content to social actors including @amnestyindo,@heradiani,@DPR_RI, and @mardiasih, presented the hashtag \#SahkanRUUPKS and mentioned to @DPR_RI and political leader Puan Maharani to immediately ratify RUU PKS. The third group with $10.99 \%$ brought discourse related to the invitation to discuss "Time Without Books" the survivors of the dictatorships in Uruguay and Aceh and mentioned several related actors such as @ Wanitabaca,@magdalenid,@KontraS, and@jakartafeminist, and shows a wedge between the discourse of feminism and human rights. The fourth group with $7.69 \%$ is a network subgroup of the second group. The fifth group with $5.4 \%$ brought the discourse of inviting discussion and writing for women's rights, also a subgroup of the second group network. The sixth group with $4.4 \%$ brought the discourse of an invitation to work part-time as a data analyst at feminist Jakarta made by @waltonkate. The seventh group with $4.03 \%$ brought the discourse of calling for activism related to the \#16days \#orangetheworld UN Women agenda the UNiTE program “Orange the World: Fund, Respond, Prevent, Collect!” In 2020, 
held from 25 November to December 10 every year (UN Women 2020), the hashtag was related to activist @Lini_ZQ. The eighth group with $4.03 \%$ brought the discourse of advocacy requests for victims of sexual harassment and was directed to several related actors such as@LBHAPIK, @RahayuSaraswati, @waltonkate,@mardiasih, and @anindyavivi.

\section{Women's March Jakarta through Twitter mobilization}

The effectiveness of social media as a mobilization tool supported by an established network and collective identity ownership are the determining factors of the mobilization process (Suwana 2020, Muller 1980). Mobilization based on McCarthy \& Zald (1997) is a process of distributing resources to support the protests. The subject determining the occurrence of mobilization can be individual activists or groups as well as movement organizations (Sokolov et al. 2018). Jakarta Feminist have an established network of ties as mentioned above and built through strong network ties (family and friends) and weak ties (strangers meet and participate on/through social media) networks to mobilize. The weak ties could be a stronger basis for mobilization than strong ties (are exclusive and exclude the collaboration with various potential movement allies) (Granovetter 1973). Jakarta Feminist has known been mobilized WMJ, in 2021, they are bringing \#PuandanKawanMelawan and demanded several points such as: urging the ratification of laws and policies regarding gender-based violence in various fields, equality in the field of employment and labor, and repealing laws that harm society from various lines, and the passage of laws that favor the community, women, minority, other vulnerable groups, and eliminate violence, discrimination, and repression (womensmarchjkt 2021). We analyzed and found the Twitter network data of \#PuandanKawanMelawan which was taken while WMJ 2021 was run on April 16-26, with SNA and TNA has identified 304 nodes and 576 edges and 273 nodes, and 743 edges. There are 12 groups of actors (Figure 3), and 19 corpuses (Figure 4).

Based on modularity, the first group with $34.87 \%$ consisted of 107 actors and led to two namely @BTS AHC_IDN,@itswidis. These accounts havethestrongestinfluencein the overall\#PuandanKawanMelawan network@BTS_AHC_ID counts 1 and has 128 ties, and @itswidis 0.570312 and has 73 ties based on Eigenvector and degree centrality (Table 2) count. The second group with $21.05 \%$ consisted of 64 actors and led to several accounts such as@journalin,@ARMYactivist, @womensmarchjkt. In the group of actors, there were two influential accounts based on eigenvector centrality in the network including @ journalin as much as 0.289062, @womensmarchjkt as much as 0.507812, and each got 71 ties and 65 ties, as well as the @Gustika. The third group with 20.39\% consists of 62 accounts and is mentioned on the@marinnaraz account as one of the influential actors in the network, accounting for 0.484375 based on eigenvector centrality. The fourth group with $8.88 \%$ consists of 27 actors and mentioned to several accounts such as@waltonkate, @novalauliady,@amnestyindo, and @dpr_ri. The fifth group with $4.28 \%$ consists of 13 actors and leads to the account @hollahalipah28. The sixth group with 2.3\% consists of 7 actors and mentioned to the account @shofiagunawan. The seventh group consists of 4 actors with ties pointing to the @ cutieliljoonie account while the eighth group consists of 6 actors and is mentioned on the @ KoalisiSeni account. In the ninth group with 1.64\% consisting of 5 actors and ties mentioned to @yacko. The tenth group with 1.32\% consisting of 4 actors and ties/relationships mentioned to@RahayuSaraswati. The eleventh group with 0.66\% mentioned to @dikahamid and the twelfth group with $0.66 \%$ mentioned to @journalin.

Table 2.

The actor's degree centrality and eigenvector centrality of \#PuandanKawan social network

\begin{tabular}{|c|c|c|c|c|}
\hline No. & Actor & $\begin{array}{c}\text { Number of } \\
\text { connections/ties }\end{array}$ & Actor & $\begin{array}{c}\text { Influence/Eigenvector } \\
\text { Centrality }\end{array}$ \\
\hline 1. & @BTS_AHC_IDN & 128 & @BTS_AHC_IDN & 1 \\
\hline 2. & @itswidis & 73 & @itswidis & 0.570312 \\
\hline 3. & @journalin & 71 & @womensmarchjkt & 0.507812 \\
\hline 4. & @womensmarchjkt & 65 & @marinnaraz & 0.484375 \\
\hline 5. & @amnestyindo & 15 & @journalin & 0.289062 \\
\hline
\end{tabular}




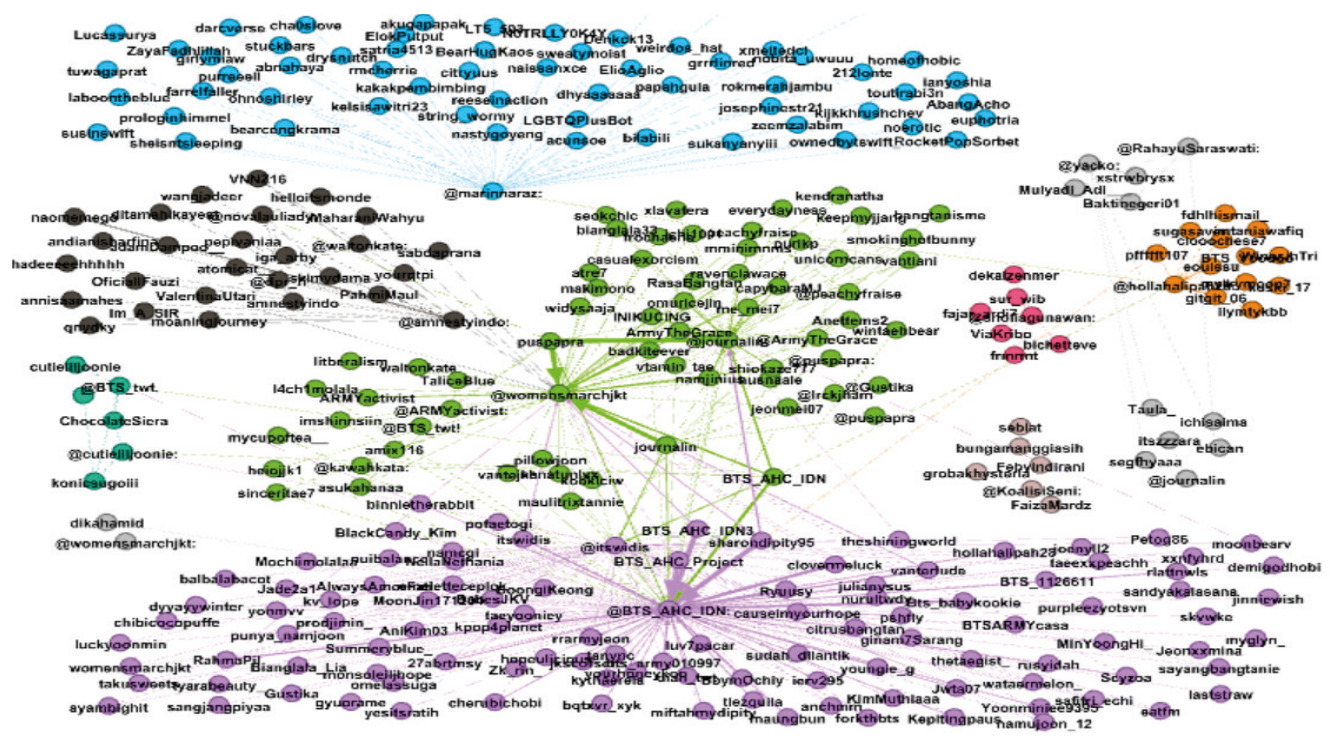

Figure 3.

Social network graph of \#PuandanKawanMelawan

Source: Personal data

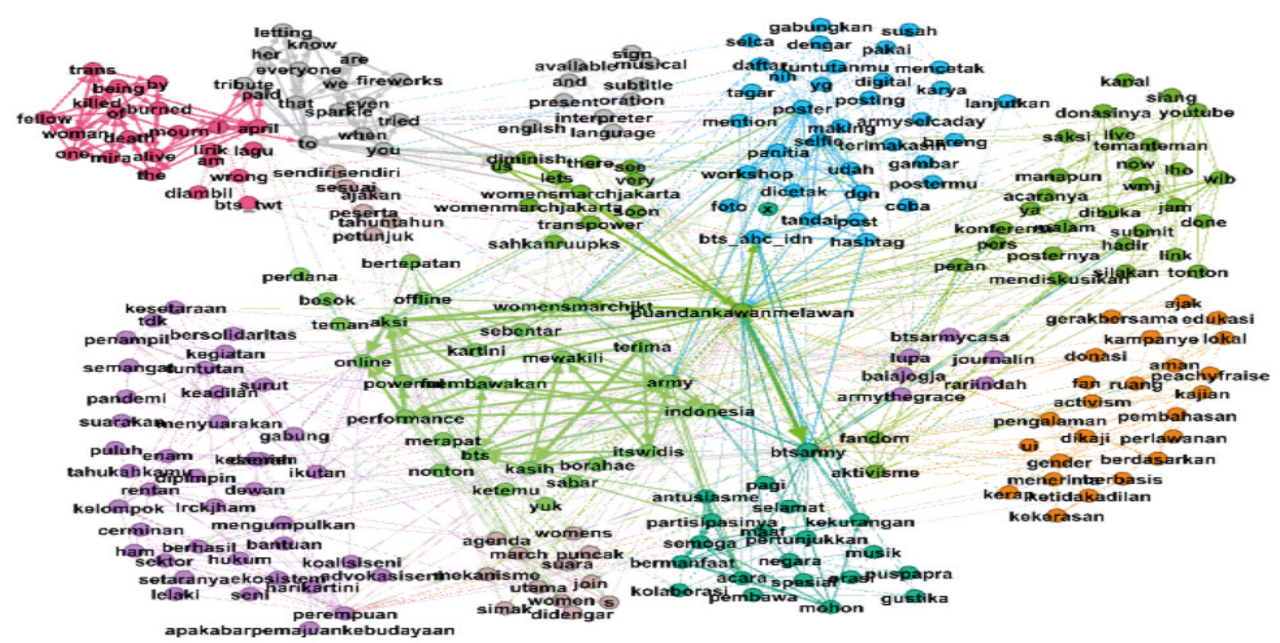

Figure 4.

Textual network graph of \#PuandanKawanMelawan Source: Personal data

The TNA is as follows: the first group with $30.32 \%$ brought a discourse about an invitation to collaborate on online activism WMJ 2021 and the K-pop Idol fan base BTS_AHC_IDN called ARMY group, discussed the experience of female fandom often experiencing gender injustice and violence, resistance with local activism, providing safe spaces, education, campaigns, donations, and some accounts are mentioned as the orator@puspapra, host@Gustika, material reviewer@peachyfraise, while several other actors such as the organization defending digital rights in Southeast Asia@safenetvoice. The second group with $15.52 \%$ brought a discourse of an invitation to campaign a workshop poster making for participants of WMJ 2021, which is digital posters to voice the demands and inserted \#PuandanKawanMelawan \#WMJ2021. The third group with $15.16 \%$ brought a discourse on women's representation in the Regional Arts Council in Indonesia, mentioned that there were only four women from sixty-one Regional Arts Councils in Indonesia which indicates that women are not equal with men in many sectors, including the art ecosystem, also carried \#koalisiseni, \#advocation of art, \#harikartini, \#puandankawanmelawan, and \#apakabarpemajuankebudayaan. The fourth group with 9.75\% spoke about speeches at WMJ 2021 which had been facilitated by an English translator and information about the instructions and regulations for the street demonstrations on April 21-23, 2021, to avoid crowds when expressing support. The fifth 
group with $7.58 \%$ discussing the contribution of the @itswidis as a representative of the BTS_AHC_IDN in the WMJ 2021. The sixth group with $6.5 \%$ and seven with $6.14 \%$ had the same discourse regarding the case of Mira's death, a transgender woman who was burnt on April 4, 2020, in Cilincing, North Jakarta. The eighth group with $2.58 \%$ discussing appreciation to the WMJ 2021 initiator and the ARMY group who had participated in their online activism. The ninth group with $1.44 \%$ had a discourse an invitation to urge the House of Representatives of the Republic of Indonesia with the @dpr_ri account to ratify RUU PKS and the Draft Law on Domestic Workers (RUU PPRT) by filling out petitions, submitted@womensmarchjkt by inserting \#PuandanKawanMelawan. The tenth group with 1.08\% brought a discourse call to join the WMJ 2021 and inserting \#puandkankawanmelawan, \#wmj2021, \#SahkanRUUPKS, and mentioned by @womensmarchjkt. The eleventh with 0.78\% discourse is an invitation brought by @yacko to join the WMJ 2021 and insert \#PuandanKawanMelawan. The twelfth to nineteenth groups each have the same percentage of $0.36 \%$ with a discourse about for every $15 \%$ decrease in essential services in 6 months will result in the death of 235,500 children and 12,190 maternal deaths and explain the importance to maintain essential services, and demand to promote inclusive, stigma-free, and discrimination-free health systems.

\section{Conclusion}

Jakarta feminists form a collective identity based on their member's identity, concern, and defense for the rights of women and minority groups in Indonesia. They have resources as follows; First, moral resources with legitimacy validation as an organization by relevant state institutions, solidarity obtained joining feminist movements on a local-global scale, and sympathy by bringing the problems of the representatives of its members into collective problems which become a common problem and mentioned to their demands. Second, cultural resources as their feminist knowledge and capacity to spread it through other social and public media campaigns such as community gatherings, hangouts, reading feminist book clubs, film screenings, and feminist festivals. Third, socio-organizational resource as 8 staff in their structural organization and the alliances over 30 communities and 65 organizations joining WMJ over years. Forth, material, financial, and physical resources as digital technology (Twitter), internal funding by the members and several commercial public events, and the presence of their members or broader as participants who join their activism, events, and WMJ. Fifth, human resources as many as 2,388 who have become members, professional entities, influential actors in social media, both all participate in sustaining their activism. Last, network resources as ties brought by their members.

The network coordination was arranged by member's ties to their affiliation, and it's known from the SNA results in @jakartafeminist Twitter social network showed that the actors are diverse both of its was individual, organization, local and global entities. Forth, the information disseminates creatively by their members through social media by taking advantage of its available features such as hashtags, indirect intertwin relationship with social media personality actors, and the cross-sectional discourses such as feminist to human right, feminist, and art, to structural issues, and so on. The WMJ 2021 mobilization process by conducting internal group planning, determining themes and hashtags, digital campaigns carried out by social media personalities actors, and alliances with other individual and/ or cross-organization, hence the SNA and TNA of \#PuandanKawan Twitter network results show that the alliances with cross-organization become successfully implemented online. For future research, an explanation of the intersectional phenomenon between digital feminist activism and other affiliations can be an interesting consideration as it found in the SNA data's result the intersectional relation of feminist issues to certain fandom groups.

\section{References}

Arnaboldi M, Bosco C, \& Cungensan S (2017) Accounting, accountability, social media and big data: Revolution or hype. Accounting, Auditing \& Accountability Journal 30 (4):762-776.

Blondel V, Guillaume JL, Lambiotte R, \& Lefebvre E (2008) Fast unfolding of communities in large networks. Journal of Statistical Mechanics Theory and Experiment. 
Buechler SM (1990) Women's Movements in the United States. New Brunswick NJ: Rutgers.

Castells M (2000) The rise of the network society. Oxford, Blackwell Publishers.

Chafetz JS (2006) The Varieties of Gender Theory in Sociology. In Chafetz JS (Eds.) Handbook of the Sociology of Gender. Verlag US: Springer.

Crenshaw K, Ritche AJ, Anspach R, Gilmer R, \& Harris L (2017) Say Her Name: Resisting Police Brutality Against Black Women. African American Policy Forum. https://ncvc.dspacedirect.org/ handle/20.500.11990/1926.

Denzin N K (1978) Sociological Methods. New York: McGraw- Hill.

Edwards B \& McCarthy JD (2004) The Blackwell Companion to Social Movements. Massachusetts: Blackwell Publishing.

Gerbaudo P \& Treré E (2015) In search of the "we" of social media activism: Introduction to the special issue on social media and protest identities. Information, Communication \& Society 18: 865-871.

Granovetter M (1973) The strength of the weak ties. American Journal of Sociology 78: 1360-1380.

Gruzd A \& Mai P (2020) Going viral: How a single tweet spawned a COVID-19 conspiracy theory on Twitter. Big Data \& Society 7 (2). https://doi.org/10.1177/2053951720938405.

Isa D \& Himelboim I (2018) A social networks approach to online social movement: Social Mediators and mediated content in \#FreeAJStaff Twitter network. European Journal of International Relations 367-389. https://doi.org/10.1177/1354066195001003003.

Jackson S (2018) Young feminists, feminism and digital media. Feminism \& Psychology 28 (1): 32-49.

Jamierson A (2016) Women's March on Washington: A guide to the post-inaugural social justice event. [Accessed 10 April 2020]. https://www.theguardian.com/us-news/2016/dec/27/womens-marchon-washington-dc-guide.

KPI (2016) Nyala lilin untuk keadilan YY. [Accessed April 10 2020]. https://www.koalisiperempuan. or.id/2016/05/09/nyala-lilin-untuk-keadilan-yy/.

McAdam D (1992) Gender as a mediator of the activist experience: The case of freedom summer. American Journal of Sociology 97: 1211-1249.

McCarthy JD \& Zald MN (1977) Resource mobilization and social movements: A partial theory. American Journal of Sociology 82: 1212-1241.

Melucci A (1998) Challenging Codes: Collective Action in the Information Age. Cambridge: Cambridge University Press.

Miles BM \& Huberman M (1992) Analisis Data Kualitatif Buku Sumber Tentang Metode-Metode Baru. Jakarta: UIP.

Muller E (1980) From mobilization to revolution. By Charles Tilly. (Reading, Mass.: Addison-Wesley 1978). American Political Science Review 74 (4):1071-1073. https://doi.org/10.2307/1954345.

Morris AD (1984) The Origins of the Civil Rights Movement: Black Communities Organizing for Change. New York: The Free Press.

PalysT \&AtachisonC(2012)Qualitativeresearchinthedigitalera:Obstaclesandopportunities.International Journal of Qualitative Methods 352-367. https://doi.org/10.1177/160940691201100404.

Parahita GD (2019) The rise of Indonesian feminist activism on social media. Jurnal Komunikasi ISKI 4 (2):104-115.

Pelak, CF, Taylor V, \& Whittier N (2006) Gender Movements. In J.S Chafetz (Ed.) Handbook of the Sociology of Gender. New York: Springer.

Saud M \& Margono H (2021) Indonesia's rise in digital democracy and youth's political participation. Journal of Information Technology \& Politics 18 (4):443-454.

Segev E (2020) Textual network analysis: Detecting prevailing themes and biases in international news and social media. Sociology Compass 14 (4). https://doi.org/10.1111/soc4.12779.

Sokolov A, Olenitskaya C, \& Golovin Y (2018) Success factors of internet-activism in social networks. SHS Web of Conferences 50 (01175):1-8.

Suwana, F (2020) What motivates digital activism? The case of the Save KPK movement in Indonesia. Information, Communication \& Society 23 (9):1295-1310.

Suwana F (2021) Indonesian young people and digital activism: Digital preferences and strategies to participate in social and political engagement. ECPR General Conference Virtual Event, 30 August-3 September. 
Swank S \& Fahs B (2017). Understanding feminist activism among women: Resources, consciousness, and social networks. Socius: Sociological Research for a Dynamic World 3: 1-9.

Tarrow S (2011) Power in Movement: Social Movements, Collective Action, and Mass Politics. New York: Cambridge University Press.

Turner R \& Killian L (1987) Collective Behavior. Englewood Cliffs NJ: Prentice-Hall.

UN Women (2020) 16 days of activism against gender-based violence: 2020 UNiTE Campaign Theme: “Orange the World: Fund, Respond, Prevent, Collect!". [Accessed 23 April 2020]. https://www. unwomen.org/en/what-we-do/ending-violence-against-women/take-action/16-days-of-activism.

Vogt C \& Chen P (2001) Feminisms and the Internet. Peace Review 13 (3):371-374.

Williams ML \& Burnap P (2016) Using Twitter for criminology research. British Sociological Association. [Accessed 07 September 2021]. https://www.britsoc.co.uk/media/24899/usingtwitter-for-criminology-research.pdf.

Wasserman S \& Fraust K (1994) Social Network Analysis: Methods and Applications. Cambridge: Cambridge University Press.

Wijayanti MM \& Rosalinda H (2020) The role of women in the management of Family Hope Program fund in Surabaya. Jurnal Sosiologi Dialektika 15 (2):64-71.

Wismabrata MH (2020) Banyak kasus keguguran, ratusan buruh es krim Aice mogok dan tuntut "shift" malam dihapus. [Accessed 10 April 2020]. https://regional.kompas.com/ $\mathrm{read} / 2020 / 02 / 28 / 20550061 /$ banyak-kasus-keguguran-ratusan-buruh-es-krim-aice-mogok-dantuntut-shift?page=all.

womensmarchjkt (2021) Apa saja sih tuntutan yang mereka perjuangkan? Yuk lihat! Inilah tuntutan di Women's March Jakarta yang didukung para perempuan Indonesia. Ikut suarakan dan perjuangkan dengan capture dan post tuntutan yang kamu dukung di Women's March Jakarta 2021, saatnya kita didengar \#PuandanKawanMelawan. [Accessed 18 April 2021]. https://www.instagram. $\mathrm{com} / \mathrm{p} / \mathrm{CNzpFhbgOlN} /$ ?utm_source=ig_web_copy_link.

Zeng J (2020) \#MeToo as connective action: A study of the anti-sexual harassment campaign on chinese social media in 2018. Journalism Practice 14 (2):171-190. 